\title{
Discussion on the Improvement of Chinese Labor Standard Legal System
}

\author{
Yuan Liu \\ Northwestern Polytechnical Univercity \\ Xi'an, China 710072 \\ Shaanxi academy of social science \\ Xi'an, China 710065
}

\begin{abstract}
Labor standard legal system is an important legal system to adjust labor relations,but there are some problems in its designing and operation,such as the protection of labor's Collective negotiation right and social insurance right. It is therefore necessary to further explore specific measures to improve Chinese labor standard legal system, starting with the guiding ideology of Chinese labor standard legal system.
\end{abstract}

Keywords-labor standard; Collective negotiation right; social insurance

\section{INTRODUCTION}

Labor standards in China, refers to employers must guarantee the minimum labor rights of laborers and labor treatment in the labor standards law provisions of the state. National labor standards were released on the territory of China, all the laborer and employers have must abide by the law of compulsory generally. [1] 82 the labor standards law system should include two levels of content: the first, involving workers basic rights such as right to survival and development of legal system, and efficient continuation of labor legal system, such as minimum wages, working hours, labor security, labor age, Labour insurance, legal system of laborers' health. Secondly, involved in order to realize the first level as the goal of related rights of the legal system, mainly is the International Labor Organization in 1998 through the basic labor rights declaration of principles specified in the "core labor standard" : (1) the freedom of association and effectively recognize collective bargaining; (2) to eliminate all forms of forced labor; (3) the effective abolition of child labor; (4) the elimination of employment discrimination. [2] In the fourth, five, six, seven chapter of Chinese Labor law do the rules to wages, working hours, rest and vacation, labor safety and health, the content of the protection of female workers and juvenile workers. The second chapter and the third chapter of Labor law and Employment promotion law made rules to ensure fair employment. But with the development of the practice it show some of these provisions, make it can't be implemented effectively, so it is necessary to further improve from the guiding ideology of the labor standards law system.

\section{THE MAIN PROBLEMS OF THE LABOR STANDARDS LAW SYSTEM IN OUR COUNTRY}

\section{A. Current Labor Standards Law System Has Not Been Fully Implemented}

According to the National People's Congress law enforcement inspection group about the inspection report on the implementation of the "labor law of the People's Republic of China" made by he luli, vice chairman of the standing committee of the National People's Congress, in the 19th meeting of the tenth National People's Congress standing committee meeting, we know that the problems in implementation of the labor standards is mainly manifested in three aspects: first, the minimum wage protection system has not been fully implemented, the phenomenon of unpaid wages still happen, salary has not been a normal growth mechanism. According to the inspection group questionnaire survey, in the past year, $7.8 \%$ of workers are owed wages, salaries average was 3.2 months in arrears, unpaid amount per capita 2184 yuan, the serious problem of $16.1 \%$ of employees unpaid wages. At the same time, some enterprise workers salary under standard of local minimum wage. Second, excessive overtime phenomenon is relatively common, poor working conditions. According to the labor bureau Songjiang district of Shanghai, in nearly five years of labor inspection cases more than $40 \%$ of companies failed to comply with the labor law overtime. According to China's finance and the spinning of tobacco trade union 5 provinces of Zhejiang, Jiangsu, Hebei, according to a survey of textile industry, farmers man-days working time is generally within 12 hours, monthly average working hours is 306 hours, up to 139 hours of overtime, working overtime is the law allows the highest limit of 36 hours of 3.86 times. [3] third, narrow social insurance coverage, low level as a whole, such insurance premium phenomenon is serious. According to statistics, there are $80 \%$ of workers in our country and the old people have no basic endowment insurance, $90 \%$ of people lack of basic medical insurance, the vast majority of female worker bears insurance, rural poverty population has not been institutionalized the lowest life guarantee and so on. $[4]^{76}$ 


\section{B. Laborer Social Insurance Rights Relief Mechanism Is Not Sound}

The laborers right to social security payments problems in three aspects: one is for "the supplementary endowment insurance" ruling and judgment can't perform. In view of the reality of employers not of pay or pay endowment insurance, arbitration institution by ruling and court by the verdict of unit of choose and employ persons pay endowment insurance, but when employers to pay social security department is refused, the reason is that there are no national relevant policies allow fill, which may lead to a ruling or judgment cannot execute; the second is that employers did not pay the birth insurance, inductrial injury insurance, medical insurance, unemployment insurance. Arbitration or court according to the characteristics of the above insurance (inherent), often do not support "require companies to pay above insurance" put forward by the workers of the request. Although this practice was legal, but the rights and interests of workers is not guaranteed, because laborer is in the above insurance accident happened when own expenses and losses without compensation. The third is the shortage of the limitation of administrative supervision regulations. According to the article 27 of labor dispute mediation arbitration law, "the limitation of labor dispute arbitration is one year. The limitation of arbitration from the party knew or should have known that its rights infringement calculation ". in article 20 of the labor security supervision regulations stipulated:" within two years from being discovered by the administrative department of labor and social security, also is not reporting, complaints, the administrative department for labor security no longer is investigated. "This, of course, is more advantageous to protect the lawful rights and interests of workers, and more conducive to the rational allocation of social resources, but the provision in the design. There are some drawbacks in the original time limitation of labor security supervision shall be under the jurisdiction of no clear, such as social insurance and other issues, even after two years, supervision organization can tube. However, if the entity problem now after 2 years without punishment, the laborers' right to relief will collapse, it is unreasonable for workers' rights guarantee.

\section{The Workers Collective-bargaining Rights Guarantee Mechanism Is Not Perfect}

Basis labor law, collective contract issued by the ministry of labor in December 1994, as well as trial measures on settling wages through collective negotiations issued by the ministry of Labour and social security on November 8 in 2000 , the relevant provisions of the collective consultation and collective contract system is to coordinate the effective mechanism of labor relations under the market economy, is to safeguard the worker labor rights and democratic rights and the focus of the work. However, China's trade unions in the process of implementation of the collective contract, despite the government's support, but still by employers not cooperative or resistance, or are not obeyed, make it become a mere formality or control negotiation. In the aspect of legal system, although the article 53 of the trade union act of 2001 added on the provision of unit of choose and employ persons refuse to collective bargaining: "in violation of the provisions of this law, any of the following circumstances, to the people's government at the county level shall order correction, deal with according to law;... without justifiable reason to refuse to carry on the equal consultations." But there is no clear "warrant", "processing" in accordance with the specific content, make collective bargaining rights cannot get effective guarantee.

\section{PERFECTING THE GUIDING IDEOLOGY OF THE LABOR STANDARDS LAW SYSTEM IN CHINA}

To perfect our system of the labor standards law shall reflect the thought of "double protection of sloping protection", namely the protection on the basis of the legitimate rights and interests of parties of labor relations, focusing on the protection of the legitimate rights and interests of workers. "Double protection" means that the construction of labor relations law safeguard mechanism of our country is not simply to protect one of the labor relations, but the labor relations effectively protect the legitimate rights and interests of both parties, because of the labor standards to determine not only involves the rights and interests of labourers, also involves the employers labor costs and social responsibilities, embodied in the guarantee of the development rights of laborer survival, to promote effective metabolism and the continuation of a country labor force, as the main social and human development and social development, is closely related to the employer's interests and development. High labor standards, employers of high labor costs and have to bear the social responsibility; Low labor standards, employers labor costs low and small have to bear the social responsibility. Tilt at the same time, the labor standards law should be "legislation", the key question now is need in the concrete system of the labor standards law embodies the "tilt" legislation thought, for example, should be perfected to worker pay of the relevant laws and regulations. At present, the wage payment compared with other countries and regions of the relevant provisions of the obvious deficiencies. Such as France respectively established wage claims priority in legislation and system of salary pays insurance gold. The protection of wages on insolvency ordinance of Hong Kong provides: set up a committee of wages on insolvency, employer or employees of wages on insolvency can apply to the commission, after check, the commission scrutiny allocated from the fund. [5] ${ }^{52}$ To that end, we also can consider to build system of wage claims priority and pay insurance gold, solve the laborer from the legal system, especially the wages paid to the underlying problem.

The labor standards law system in China should be "low standard, broad cover, strict law enforcement" as the goal. [6] 52 "low standard, broad cover" has three layers of meaning: one is compatible with realistic productive forces level of development in our country. China's economy is growing fast in recent years, but because of China's big population base, per capita gross national product (GNP) compared with the developed countries is still very low, therefore, our country's labor standards can not reach the standard of developed countries, only according to the per capita gross national product (GNP) as the standard, based on the local 
economic development level, formulate the corresponding labor standards; The second is embodies the protection of laborers. The development level of laborers in our country is different, a few workers life richer, competition ability is strong, they are not the center of the labor standards law protection, while most of the workers at the bottom of the labor force, they belong to the low skills, older, less competitive, liquidity is stronger, more easily be alternative of ordinary workers, for the labor standards are looking forward to the most urgent, is the key of the labor standards law protection, therefore, the labor standards law shall be established by means of labor standards to the underlying the interests of labourers to special protection. The third is embodies the protection of employers. We generally from the perspective of workers to understand the meaning of "low standards, wide coverage", this is only partial. Because of the development of employers also inseparable and realistic productive forces level of development, our country realistic economic development shows that in our country, really have advanced management experience, high-tech content, reflect the strong competitive power of enterprises are in the minority, more enterprises mainly rely on cheap Labour to the survival and development, labor standards set too high, if can make the most of enterprises are facing bankruptcy, which would affect the economic development of our country. So in this sense, "low standard, broad cover" also embodies the protection of employers. Of course, this does not mean "low standard" static, labor standards will gradually increase with raising the level of productivity development in our country, this process is the same with enterprise competitiveness in our country by relying on cheap labor to rely on high-tech transformation and enhance and improve labor for quality in our country and the survival and development of standards to improve process. "Wide coverage" is the same, no matter how productivity development to a high level, the determination of the labor standards are always consider the interests of the laborers and the interests of the vast enterprise. "Strict law enforcement," refers to the established labor standards, we should be in strict accordance with the labor security supervision, mediation and arbitration of labor, the regulation of the legal system of labor dispute litigation, strengthen labor relations to establish, maintain and remove after the relevant supervision and law enforcement of labor standards, make labor standards into practice.

\section{CONCRETE MEASURES OF PERFECTING OUR COUNTRY'S LEGAL SYSTEM OF THE LABOR STANDARDS}

\section{A. To Develop Specialized Labor Standards Act}

There are two main types of the labor standards law style: one is a separate set of labor standards act, such as the America fair labor standards act, the Japanese labor standards act, etc. Another kind is to the labor standards law specification included in the comprehensive legislation, such as the French labor code. After our country labor law basically belongs to a kind of legislative model, there are some in the labor law of the labor standards law norms. [6] ${ }^{52}$ But in our country in 1994 promulgated the labor law the provisions of labor standards are too principle, lack of maneuverability, such as the law of labor remuneration, only principles such as the minimum wage standard, which is difficult to implement in practice. Especially the law not about punishment for violations of labor standards for clear and detailed standard, make it impossible to effectively prevent and stop the violation of labor standards. In view of this, the author argues that a separate accord with China's national conditions and social development needs of the labor standards law, embodies the thought of "double protection of sloping protection", to "low standard, broad cover, strict law enforcement" as the goal, to distinguish between form and industry form of unit of choose and employ persons, respectively, to determine the different labor standards, supplemented by administrative penalties and criminal penalties to guarantee its implementation, to protect the labor rights of laborers, maintenance work conditions to realize the basic level, finally promote the development of social economy.

\section{B. Perfect the Supervision of the Implementation of Labor Standards Guarantee Mechanism}

Aiming at the public power supervision in the implementation of labor standards in China the status of the lack of security, the author thinks that, on the one hand, should continue to perfect the legal system of labor inspection, to strengthen the effectiveness of labor administrative supervision.First of all, for labor dispute involving social insurance, apply to the labor inspection limitation from calculated from the date of the working relationship removes, more conducive to protect the lawful rights and interests of workers. Second, the labor inspection scope of strict limits should be placed in the execution of the enterprise state within the scope of the labor standards law. On the other hand, should pay attention to the function of folk, the non-public power strength the supervision of the implementation of labor standards and safeguard the positive role, in order to make up for the inadequacy of public power supervision power. Folk nongovernmental organizations (ngos) the supervision of the implementation of labor standards and security forces, mainly from two aspects, one is some intermediary agencies and non-governmental organizations; Secondly, the relevant industry association autonomy organization, etc. Association of enterprises can through the internal education and cultivating the collective consciousness, or create an environment to affect a member of the association of common values and culture, to continue and strengthen group cohesion, prompting group members take the initiative to assume for its legal responsibility.

\section{Maintain the Laborers' Right to Collective Bargaining}

Maintain the laborers' right to collective bargaining solution: one is to strengthen the union of collective bargaining, the article 6 of Chinese labor contract law has been clear about the trade union in with employers remove and terminate the non-fixed term labor contract the terms of collective bargaining to protect the lawful rights and interests of workers. The second is to strengthen the employer's legal liability. Should formulate detailed rules for the implementation of labor law as soon as possible, labor law clearly stipulated in article 53 through equal consultation 
employers refused to in the scope of the "warrant" and the government in order to remedy the situation "instruct unit of choose and employ persons is correct" and the specific content of "handled in accordance with the law to unit of choose and employ persons; The third is to fully respect the worker's opinions and requirements. "Labor law" stipulated in article 27: "enterprises, institutions, go-slow event happened shutdown, trade union shall on behalf of the workers with enterprises, institutions or related consultation, reflect the worker's opinions and puts forward the opinions and requirements. For the worker's reasonable requirements, enterprises and institutions shall be solved. Trade unions shall assist the enterprises and institutions to do good work, restore order of production, work as soon as possible." Four is professionals such as lawyers, accountants should be allowed to enter the market of collective bargaining, in order to increase the workers and the management of collective bargaining ability, change the present our country laborer and employers of the collective bargaining is not active or become a mere formality.

\section{To Solve the Problem in the Implementation of the Social Insurance}

In carrying out the problems existing in the social insurance should be addressed from the following aspects: first, for the problems in the endowment insurance in the implementation of, perfect the corresponding national policy to implementation, such as allowing endowment insurance payment; Or through the laborer applies for arbitration or sued for compensation, arbitration institution to demand compensation from employers ruling or a judgment of the court to demand compensation from the unit of choose and employ persons. Second, the inductrial injury insurance, birth insurance, medical insurance, unemployment insurance, workers do the insurance accident, and because at that time, unit of choose and employ persons did not pay insurance premium, the cost of the actual loss shall be borne by the workers themselves, workers when applying for arbitration or file a lawsuit, claim compensation unit of choose and employ persons, arbitration institutions and the people's court shall support. If laborer puts forward "requirement of unit of choose and employ persons to fill the above insurance" litigation request, the arbitration institution or a people's court should not blindly does not support, and should draw lessons from Germany and Japan, the labor dispute lawsuit procedure, increase the arbitration institutions and the people's court of pre-trial cohabitancy rights, guide people to apply for right to arbitration or litigation request. In Germany and Japan's labor dispute, the judge attaches great importance to pre-trial preparation procedure of the judge interpretation, and the judge's interpretation of Ming as a compulsory provision. "In a lot of items in the interpretation of the Ming, guide people ask the right claim is an important content of cohabitancy." [7] ${ }^{176}$

\section{CONCLUSION}

To sum up, along with our country socialist market economy and the development of democratic rule of law, legal system about the labor standards will continue to improve, in order to effectively guarantee the harmony of labor relations.

\section{REFERENCES}

[1] shen with fairy. Implementation present situation and countermeasures of the labor standards in China [J]. Journal of legal science, 2007 (4)

[2] the international labor organization. The basic principle of labor rights declaration (1998), introduction [EB/OL] http://www.privatelaw.com.cn / new2004 / SHTML / 2004051820040518. The HTM

[3] Wang Bixue. Manufacturers excess exploitation to ignore the law worker was forced to work overtime to dare not to say [EB/OL]. http://news.xinhuanet.com/ Legal / 2005-11/30 / content_3857845. HTM, 2005-11-30

[4] qiao-feng wu. The dualism of the theory of social security system and the transformation of the social security system in China [J]. Productivity research, 2005 (2)

[5] Lin Yanqin Ding Qingguang. Migrant labor standards present situation and countermeasure research [J]. Journal of theory, 2006 (2)

[6] Mr Dong. Chinese labor the prospective method of target selection [J]. Journal of law, 2007 (1)

[7] Fan Yue. Labor dispute proceeding research [M]. Beijing: China renmin university press, 2006. P. 176 